\title{
First long-term study of particle number size distributions and new particle formation events of regional aerosol in the North China Plain
}

\author{
X. J. Shen ${ }^{1,2}$, J. Y. Sun ${ }^{1}$, Y. M. Zhang ${ }^{1}$, B. Wehner ${ }^{3}$, A. Nowak ${ }^{3}$, T. Tuch ${ }^{3}$, X. C. Zhang ${ }^{1}$, T. T. Wang ${ }^{1}$, H. G. Zhou ${ }^{4}$, \\ X. L. Zhang ${ }^{4}$, F. Dong ${ }^{4}$, W. Birmili ${ }^{3}$, and A. Wiedensohler ${ }^{3}$ \\ ${ }^{1}$ Key Laboratory for Atmospheric Chemistry of CMA, Center for Atmosphere Watch and Services, Chinese Academy of \\ Meteorological Sciences, Beijing 100081, China \\ ${ }^{2}$ Graduate University of Chinese Academy of Sciences, Beijing 100049, China \\ ${ }^{3}$ Leibniz Institute for Tropospheric Research, 04318 Leipzig, Germany \\ ${ }^{4}$ Shangdianzi Regional GAW station, Research Institute of Urban Meteorology, Beijing Meteorological Bureau, \\ Beijing 100089, China
}

Received: 8 October 2010 - Published in Atmos. Chem. Phys. Discuss.: 28 October 2010

Revised: 31 January 2011 - Accepted: 1 February 2011 - Published: 18 February 2011

\begin{abstract}
Atmospheric particle number size distributions

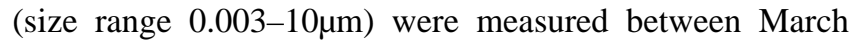
2008 and August 2009 at Shangdianzi (SDZ), a rural research station in the North China Plain. These measurements were made in an attempt to better characterize the tropospheric background aerosol in Northern China. The mean particle number concentrations of the total particle, as well as the nucleation, Aitken, accumulation and coarse mode were determined to be $1.2 \pm 0.9 \times 10^{4}, 3.6 \pm 7.9 \times 10^{3}$, $4.4 \pm 3.4 \times 10^{3}, 3.5 \pm 2.8 \times 10^{3}$ and $2 \pm 3 \mathrm{~cm}^{-3}$, respectively. A general finding was that the particle number concentration was higher during spring compared to the other seasons. The air mass origin had an important effect on the particle number concentration and new particle formation events. Air masses from northwest (i.e. inner Asia) favored the new particle formation events, while air masses from southeast showed the highest particle mass concentration. Significant diurnal variations in particle number were observed, which could be linked to new particle formation events, i.e. gas-to-particle conversion. During particle formation events, the number concentration of the nucleation mode rose up to maximum value of $10^{4} \mathrm{~cm}^{-3}$. New particle formation events were observed on $36 \%$ of the effective measurement days. The formation rate ranged from 0.7 to $72.7 \mathrm{~cm}^{-3} \mathrm{~s}^{-1}$, with a mean value of $8.0 \mathrm{~cm}^{-3} \mathrm{~s}^{-1}$. The value of the nucleation mode growth rate was in the range of $0.3-14.5 \mathrm{~nm} \mathrm{~h}^{-1}$, with a mean value of $4.3 \mathrm{~nm} \mathrm{~h}^{-1}$. It was an
\end{abstract}

Correspondence to: J. Y. Sun

(jysun@cams.cma.gov.cn) essential observation that on many occasions the nucleation mode was able to grow into the size of cloud condensation nuclei $(\mathrm{CCN})$ within a matter of several hours. Furthermore, the new particle formation was regularly followed by a measurable increase in particle mass concentration and extinction coefficient, indicative of a high abundance of condensable vapors in the atmosphere under study.

\section{Introduction}

Atmospheric aerosol particles play a key role in global climate because of combined direct and indirect radiative forcing. They directly affect the radiation balance by scattering and absorbing incoming short-wave solar radiation and absorbing long-wave radiation. Indirectly, aerosol particles have a substantial effect on cloud properties and the initiation of precipitation as cloud condensation nuclei (CCN) (Rosenfeld et al., 2008). The scattering and absorption of light by particles can affect atmospheric visibility (Middleton, 1952). Evidences from medical studies indicate that air pollution is a major contributor to cardiovascular and respiratory health problems (Hong et al., 2002). Hospital admissions and emergency room visits for cardiovascular and respiratory diseases are increasing with the elevated ambient particle concentrations (Dominici et al., 2006). There has been evidence of growing knowledge regarding pathophysiological pathways that link PM exposure with cardiopulmonary morbidity and mortality (Pope III and Dockery, 2006). The number size distribution is an important characteristic, which can help to understand the behavior and effects of the aerosol particles

Published by Copernicus Publications on behalf of the European Geosciences Union. 
(Birmili et al., 2001). Particle number size distributions can be measured down to sizes as small as $3 \mathrm{~nm}$ in diameter with high time resolution due to recent developments in instrumentation (Kulmala et al., 2004), but the latest developments have extended detection limits to sizes below $2 \mathrm{~nm}$ (Kulmala et al., 2007; Iida et al., 2009; Sipilä et al., 2009).

Ground-based in situ measurements of aerosol properties such as size distribution, chemical composition, scattering and absorption coefficient have been performed at a number of sites, either at long-term monitoring sites, or as part of intensive field campaigns (Solomon et al., 2007). A wide body of in situ observations of tropospheric aerosols have been made in urban and rural areas in Europe and North America, e.g. Birmingham (Harrison et al., 1999), Atlanta (Woo et al., 2001), Helsinki (Hussein et al., 2004), Leipzig (Birmili et al., 2001; Wehner and Wiedensohler, 2003), and Pittsburgh (Stanier et al., 2004). The studies are also done at some background sites, such as Mt. Waliguan, China (Kivenäs et al., 2009) and Aspvreten, Sweden (Dal Maso et al., 2007). During the recent years, efforts have been made to characterize particle number size distributions in developing countries as well, because their air pollution problems are of significant local and even regional concern, such as in New Delhi (Laakso et al., 2006) and Beijing (Wu et al., 2008).

The formation of new particles in the atmosphere and its effects on the budget of the number concentration of submicron particles are a vital issue in atmospheric science (e.g., Seinfeld and Pandis, 1998). Particle formation increases the total number concentration of ambient submicron size particles and thereby affects climate forcing and human health (Twomey, 1977). Measurements of particle size distributions reveal new particle formation (NPF) events and growth are widespread. It is concluded that the formation rate of $3 \mathrm{~nm}$ particles is often in the range $0.01-10 \mathrm{~cm}^{-3} \mathrm{~s}^{-1}$ in the boundary layer. However, in urban areas the formation rates are often higher than this, up to $100 \mathrm{~cm}^{-3} \mathrm{~s}^{-1}$, and the rates as high as $10^{4}-10^{5} \mathrm{~cm}^{-3} \mathrm{~s}^{-1}$ are observed in coastal areas and industrial plumes (Kulmala et al., 2004). Typical particle growth rates range from 1 to $20 \mathrm{~nm} \mathrm{~h}^{-1}$ in mid-latitudes depending on the temperature and the availability of condensable vapors. The studies show that sulfuric acid plays a dominant role in new particle formation and growth (Boy et al., 2005; Riipinen et al., 2007), and organic compounds have also been thought to have the potential role (Zhang et al., 2004; Barsanti et al., 2009). Condensation and coagulation are also important for new particle formation events. Low condensation sink $(C S)$ favors nucleation because in this case the particles growth from $\sim 1 \mathrm{~nm}$ to $3 \mathrm{~nm}$ is possible before their coagulation with larger particles (Hamed et al., 2007). Coagulation has an effect on reducing nucleation mode particle number concentration (Kerminen and Kumala, 2002). Condensation and coagulation both contribute to the particle growth after nucleation (Kerminen and Kumala, 2002; Yue et al., 2010).
In China, particle number size distribution measurements were carried out in few places only. Short term measurements of particle number size distribution were performed in Pearl River Delta (Liu et al., 2008; Yue et al., 2009), a suburban site in the Yangtze River Delta (Gao et al., 2009) and vertical ultrafine particles profiles over Northern China coastal areas (Wang et al., 2008). Long term measurements were only carried out in Beijing (Wu et al., 2008) and a remote mountain-top station, Mt. Waliguan (Kivekäs et al., 2009). There is however no data about long term of particle number size distribution measurements of the regional polluted aerosol in China yet. Thus, information on the long-term behavior of particle number size distributions is still sparse.

As a part of EUCAARI (European Integrated project on Aerosol Cloud Climate and Air Quality Interactions), joint research measurement is conducted at Shangdianzi (SDZ) regional background station by the Leibniz Institute for Tropospheric Research and Chinese Academy of Meteorological Sciences since 2008 with the purpose of better understanding the chemical and physical characteristics of atmospheric aerosols over the North China Plain. This paper focuses on the particle size distribution measurements at SDZ from March 2008 to August 2009, and summarizes the characteristics of particle number concentration, size distribution and new particle formation events at SDZ.

\section{Experimental}

\subsection{Measurements site}

Shangdianzi regional background station (SDZ, $40^{\circ} 39^{\prime} \mathrm{N}$, $117^{\circ} 07^{\prime} \mathrm{E}, 239.9 \mathrm{~m}$ a.s.l.) is one of the regional Global Atmosphere Watch (GAW) stations in China and also one of National Atmospheric Composition Background observation and Research station system of China. It is located in the northern part of North China Plain, about $55 \mathrm{~km}$ and $150 \mathrm{~km}$ northeast of the urban areas of Miyun and Beijing, respectively. Surrounding the site, there are rolling hills with farmland, orchards and forest. The foot of the hills, that is about $2 \mathrm{~km}$ south of the station, is Shangdianzi village with about 1200 inhabitants and a small factory for screw casting. The major local economical activities within Miyun County are farming and fruit growing (Yan et al., 2008). Yanshan Mountains lies on the north of the station, and the Miyun Reservoir lies in the south-west with less than $8 \mathrm{~km}$ to the station. The Beijing-Chengde highway and Beijing-Tongliao (Chifeng) railway run on the east and west side of the station, with distances of 10 and $2 \mathrm{~km}$, respectively (Tang et al., 2007). The town closest to the station is Gubeikou, which is in northeast of SDZ and $5 \mathrm{~km}$ away, with about 10000 inhabitants. Although there are some local anthropogenic pollution sources surrounding the SDZ site, the amount is quite less compared to the emission from big cities. The observations at SDZ are representative for the North China plain, 
especially the Beijing-Tianjin-Hebei (Jing-Jin-Ji) Metropoli$\tan$ region, if the air mass originate from south. Figure 1 shows the location of SDZ and some cities around, like Beijing, Tianjin, Tangshan, Shijiazhuang. The northern regions of SDZ are much less inhabited and the industrial activities are less prevalent. The station is located on the south hill side of a valley with a northeast-southwest orientation. The southwest mouth of the valley is open to Beijing and the south plain. Due to the valley topography, the prevailing winds are northeasterly and southwesterly.

On average, the winds have strong diurnal variation with southwest in the afternoon and northeast from midnight to the next morning. The wind direction distribution at SDZ is rather typical of the larger-scale situation in the North China plain (Lin et al., 2008). According to this study, the highest temperature at SDZ appeared in summer (June-August) and the monthly mean value was about $25^{\circ} \mathrm{C}$. The lowest temperature appeared in winter (December-February) and the monthly mean value was $-5{ }^{\circ} \mathrm{C}$. The relative humidity was highest in summer while it was lowest in spring (MarchMay) and winter. The highest and lowest monthly mean values were $80 \%$ and $40 \%$, respectively. The precipitation mainly occurred from June to September. The mean monthly precipitation from June to September was $110 \mathrm{~mm}, 75 \mathrm{~mm}$, $225 \mathrm{~mm}$ and $125 \mathrm{~mm}$ during this measurement, respectively.

\subsection{Instrumentation}

Particle number size distributions from $3 \mathrm{~nm}$ (mobility diameter) to $10 \mu \mathrm{m}$ (aerodynamic diameter) were measured with a time resolution of $10 \mathrm{~min}$ for about 1.5 years at the rural site, SDZ from March 2008 to August 2009. A twin differential mobility particle sizer (TDMPS) system consisting of two differential mobility analyzers (DMA) and two condensation particle counters (CPCs, model 3010 and model 3025, TSI Inc., St Paul, USA) was used to measure particle size distributions from 3 to $850 \mathrm{~nm}$ mobility diameter (Birmili et al., 1999). Simultaneously, an aerodynamic particle sizer (APS, model 3321, TSI Inc., St Paul, USA) measured number size distributions of particles with aerodynamic diameter from $500 \mathrm{~nm}$ to $10 \mu \mathrm{m}$. The resulting distributions of APS system were converted from aerodynamic to mobility diameters supposing the aerosol particle was spherical with a density of $1.7 \mathrm{~g} \mathrm{~cm}^{-3}$, same as that used in Beijing study (Wu et al., 2008), as there was no chemical composition measurement data available at SDZ. When the aerodynamic diameter was converted to mobility diameter, the total size distributions actually covered the size range from $3 \mathrm{~nm}$ to $7.7 \mu \mathrm{m}$ in mobility diameter. A low flow $\mathrm{PM}_{10}$ inlet (aerodynamic diameter) with dryer was used to supply sample for both systems. The relative humidity within the systems was kept below $30 \%$ by adding an automatic regenerating adsorption aerosol dryer in the inlet line (Tuch et al., 2009). It ensured the comparability between different aerosol measurements. An inversion routine to retrieve diameter size distributions from measured mobility had taken into account the bipolar charge distribution, and empirically determined transfer functions of the DMAs. Size-dependent diffusional losses for the inlet pipe were also corrected by using the empirical functions given by Willeke and Baron (1993). In addition, the individual $\mathrm{CPC}$ and UCPC counting efficiencies were considered for data correction. All data were subsequently reported at standard pressure and temperature $(1013 \mathrm{hPa}$ and $273 \mathrm{~K}$ ) to provide comparability with other measurements. The number concentration at standard pressure and temperature was $10 \%$ higher than that at ambient conditions. The time used in this study is Beijing local time (UTC $+8 \mathrm{~h}$ ).

In addition, basic meteorological parameters, such as air temperature, relative humidity, wind speed and wind direction were recorded at the station and used in this investigation.

\section{Results and discussion}

A continuous 1.5 years dataset was evaluated in this investigation. Except the CPC laser broken and instrument re-location, $86 \%$ of the data was effective. The continuous dataset of particle number size distributions was integrated to calculate particle number concentrations in different size classes. In this study, diameter ranges for the nucleation mode, Aitken mode, accumulation mode, and coarse mode were chosen as 3-25 nm, 25-100 nm, $100-1000 \mathrm{~nm}$, and $>1 \mu \mathrm{m}$, respectively (Dal Maso et al., 2005). The total particle number concentration indicated particle number concentration from $3 \mathrm{~nm}$ in mobility diameter to $10 \mu \mathrm{m}$ in aerodynamic diameter. The particle volume and surface area concentrations were calculated from the measured number size distributions assuming spherical particles.

\subsection{Overview of the particle number concentration}

Nucleation mode particles are from atmospheric nucleation event which is related with the low volatile condensable gases such as sulfuric acid and growth of nanometer-scale atmospheric aerosol particles (Kulmala, 2003). Aitken mode particles are directly emitted from combustion processes, such as car traffic, and also result from condensational growth and coagulation of nucleation mode particles. In urban areas, the traffic emissions are predominant source (Wu et al., 2008), and in rural areas nucleation particles growth is more important (Stanier et al., 2004). Accumulation mode particles originate from coagulation and condensational growth of Aitken mode particles and long-range transport of air masses from polluted areas.

Statistical parameters for nucleation mode $\left(N_{\text {nuc }}\right)$, Aitken mode $\left(N_{\text {ait }}\right)$, accumulation mode $\left(N_{\text {acc }}\right)$, coarse mode $\left(N_{\text {coa }}\right)$ particles and the total particle number $\left(N_{\text {tot }}\right)$, surface area $\left(S_{\text {tot }}\right)$, and volume concentrations $\left(V_{\text {tot }}\right)$ over the entire measurement period were calculated. The 


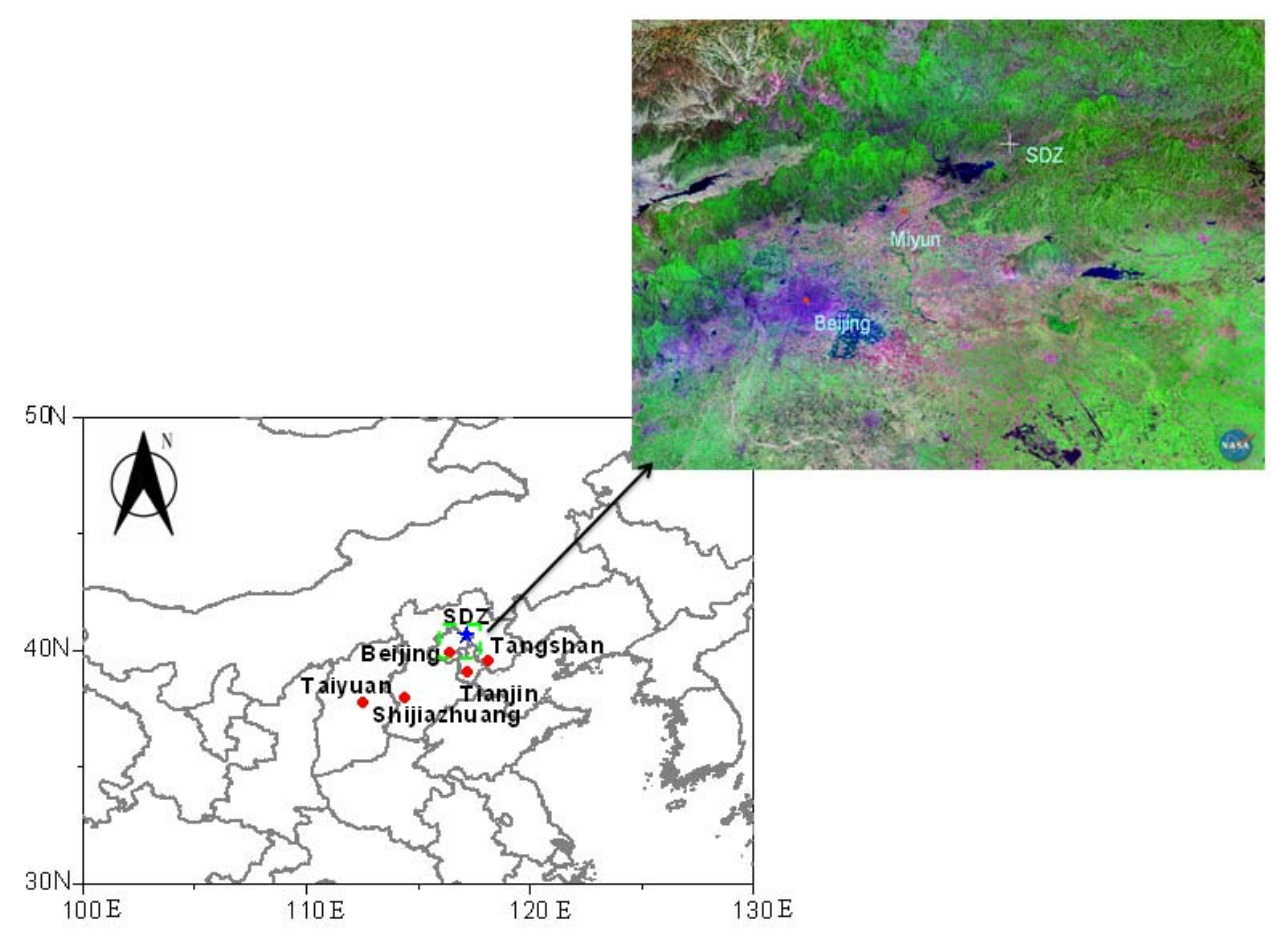

Fig. 1. Location of the SDZ station (blue star) and the main cities in Northern China (red dots) in the lower left panel. The upper right panel shows the topography and land use in the surrounding area (covered by green box), the white cross indicating SDZ station and red dots indicating Miyun county and Beijing, respectively. Green, blue and purple indicate mountains regions, river and residential areas, respectively. NLT landsat7 pseudo color map is from http://worldwind.arc.nasa.gov. Vertical exaggeration is by a factor of 3.

mean values for $N_{\text {nuc }}, N_{\text {ait }}, N_{\text {acc }}, N_{\text {coa }}$ and $N_{\text {tot }}$ were $3.6 \pm 7.9 \times 10^{3}, 4.4 \pm 3.4 \times 10^{3}, 3.5 \pm 2.8 \times 10^{3}, 2 \pm 3$ and $1.2 \pm 0.9 \times 10^{4} \mathrm{~cm}^{-3}$, respectively (" \pm " indicates standard deviation in this study). Aitken mode particles were slight higher than the other modes. The total particle surface area and volume concentrations were $690 \mu \mathrm{m}^{2} \mathrm{~cm}^{-3}$ and $50 \mu \mathrm{m}^{3} \mathrm{~cm}^{-3}$, respectively. During dust storm events, the number of coarse mode particles increased significantly. The maximum number concentration of the coarse mode particles was observed during a typical dust storm event occurred on 18 March 2008, with the value of $199 \mathrm{~cm}^{-3}$. The maximum of the particle volume concentration was observed on the same day with the value of $1560 \mu \mathrm{m}^{3} \mathrm{~cm}^{-3}$.

Table 1 is the overview of particle number concentrations measured in different urban, rural, and remote environments in China. The mean total number concentration at SDZ is much lower than that in Beijing, $32800 \mathrm{~cm}^{-3}$ (Wu et al., 2008), Shanghai suburban site, $30187 \mathrm{~cm}^{-3}$ (Gao et al., 2009), also lower than that in Jinan city, $10685-17387 \mathrm{~cm}^{-3}$ (Gao et al., 2007) and some rural sites like Yufa, $17000 \mathrm{~cm}^{-3}$ (Yue et al., 2009) and Xinken, $16300 \mathrm{~cm}^{-3}$ (Liu et al., 2008), but much higher than that at a remote background station, Mt. Waliguan, a global GAW sites in China, $2030 \mathrm{~cm}^{-3}$ (Kivekäs et al., 2009). The reason for this somewhat lower total number concentration compared to Yufa (also a regional site in the North China plain) was twofold. First, the data at Yufa covered only a time period of 4 weeks in summer 2006, and second, SDZ was on the border to the mountains in the North with very frequent influence with very clean air. The result of a back trajectory cluster analysis was shown below.

Figure 2 shows the monthly variation of particle number concentrations of nucleation mode $\left(N_{\text {nuc }}\right)$, Aitken mode $\left(N_{\text {ait }}\right)$, accumulation mode $\left(N_{\text {acc }}\right)$ and total particles $\left(N_{\text {tot }}\right)$, respectively. There were two major data gaps because CPC laser was broken in June 2008 and instruments were re-located in March 2009, where instruments were moved to a lower part of the station, about $750 \mathrm{~m}$ away because of construction work. After re-location, there were some spikes in the particle number size distribution during cooking time, and these spikes were eliminated in data evaluation. The number concentration of nucleation mode particles (Fig. 2a) showed a clear monthly variation with the minimum mean value about $1000 \mathrm{~cm}^{-3}$ in July and August 2008 while the maximum mean value was $10000 \mathrm{~cm}^{-3}$ in March 2008. This could be explained by that new particle formation events (NPF) occurred most frequently in spring and least in summer. Due to the newly formed particles growth, the mean number concentration of Aitken mode particles was higher in spring months and lower in summer months (Fig. 2b). The variation of accumulation mode 

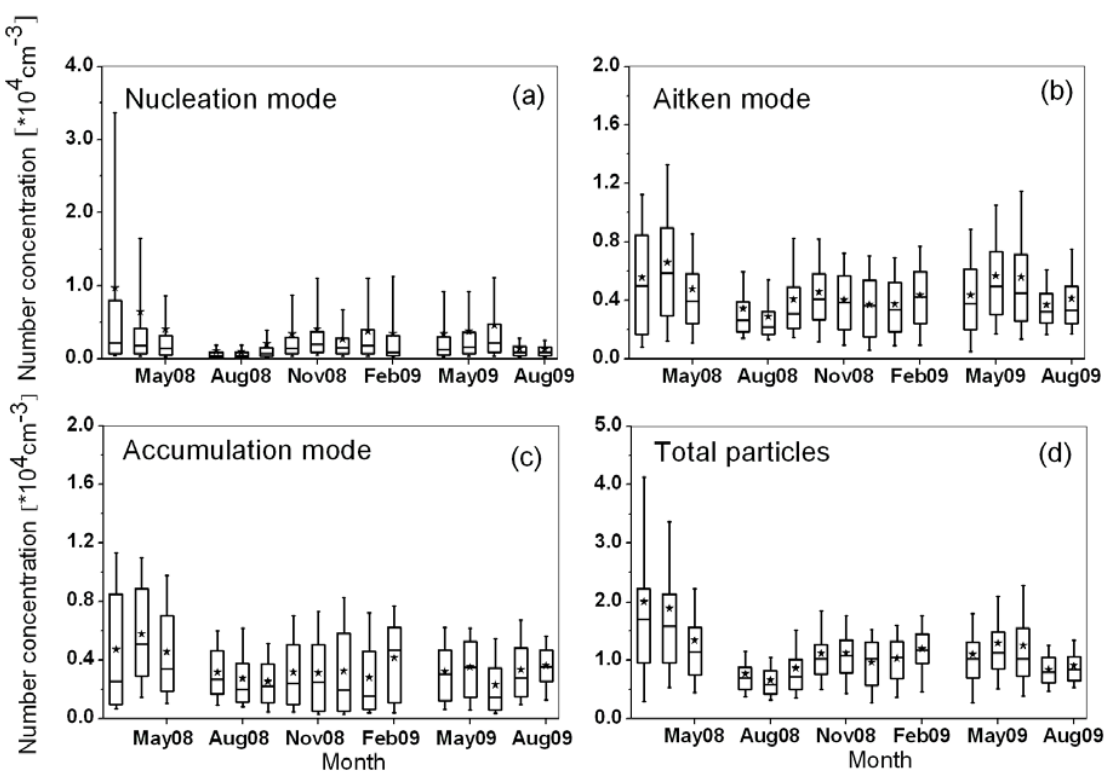

Fig. 2. Monthly variation of number concentration for nucleation mode (a), Aitken mode (b), accumulation mode particles (c) and total particles (d) at SDZ. The box plots are read as follows: the upper and lower boundaries of the box indicate the 75-th and the 25-th percentiles, the line within the box marks the median, and the whiskers above and below the box indicate the 90-th and 10-th percentiles. The stars represent the mean values. There was no data available for June 2008 and March 2009.

Table 1. Overview of experimentally determined particle number concentrations in the troposphere over China.

\begin{tabular}{|c|c|c|c|c|c|}
\hline \multirow[b]{2}{*}{ Diameter range (nm) } & \multicolumn{4}{|c|}{ Number concentration $\left(\mathrm{cm}^{-3}\right)$} & \multirow{3}{*}{$\begin{array}{l}\text { Reference } \\
\text { Wu et al. (2008) }\end{array}$} \\
\hline & $3-20$ & $20-100$ & $100-1000$ & $3-10000$ & \\
\hline Beijing, urban, 2 years & 9000 & 15900 & 7800 & 32800 & \\
\hline Diameter range (nm) & & $10-100$ & $100-500$ & $10-500$ & Gao et al. (2007) \\
\hline Jinan, urban & & & & & \\
\hline summer, 12 days & & 10300 & 385 & 10685 & \\
\hline winter, 18 days & & 15591 & 1796 & 17387 & \\
\hline Diameter range (nm) & & $10-100$ & $100-500$ & $10-500$ & Gao et al. (2009) \\
\hline $\begin{array}{l}\text { Shanghai, suburban, } \\
2 \text { months }\end{array}$ & & 28511 & 1676 & 30187 & \\
\hline Diameter range $(\mathrm{nm})$ & $3-20$ & $20-100$ & $100-1000$ & $3-10000$ & Yue et al. (2008) \\
\hline Yufa, rural, 1 month & 2000 & 9000 & 5000 & 17000 & \\
\hline Diameter range (nm) & & & & $3-10000$ & Liu et al. (2008) \\
\hline Xinken, rural/coastal,1 month & & & & 16300 & \\
\hline Diameter range (nm) & $12-21$ & $21-95$ & $95-570$ & $12-570$ & Kivekäs et al. (2009) \\
\hline $\begin{array}{l}\text { Waliguan, remote rural, } \\
22 \text { months }\end{array}$ & 570 & 1060 & 430 & 2030 & \\
\hline Diameter range (nm) & $3-25$ & $25-100$ & $100-1000$ & $3-10000$ & This work \\
\hline Shangdianzi, rural, 1.5 years & 3610 & 4430 & 3470 & 11510 & \\
\hline
\end{tabular}

particle number concentration (Fig. 2c) had the same trend with that of Aitken mode except in fall 2008 and June 2009, which was due to the Aitken mode particles grew to the size of accumulation mode by condensation mainly during air mass long-range transportation. The total particle number concentration seemed to be higher in spring months and lower in summer months (Fig. 2d), and the monthly mean concentration varied from about $6000 \mathrm{~cm}^{-3}$ to $20000 \mathrm{~cm}^{-3}$. 

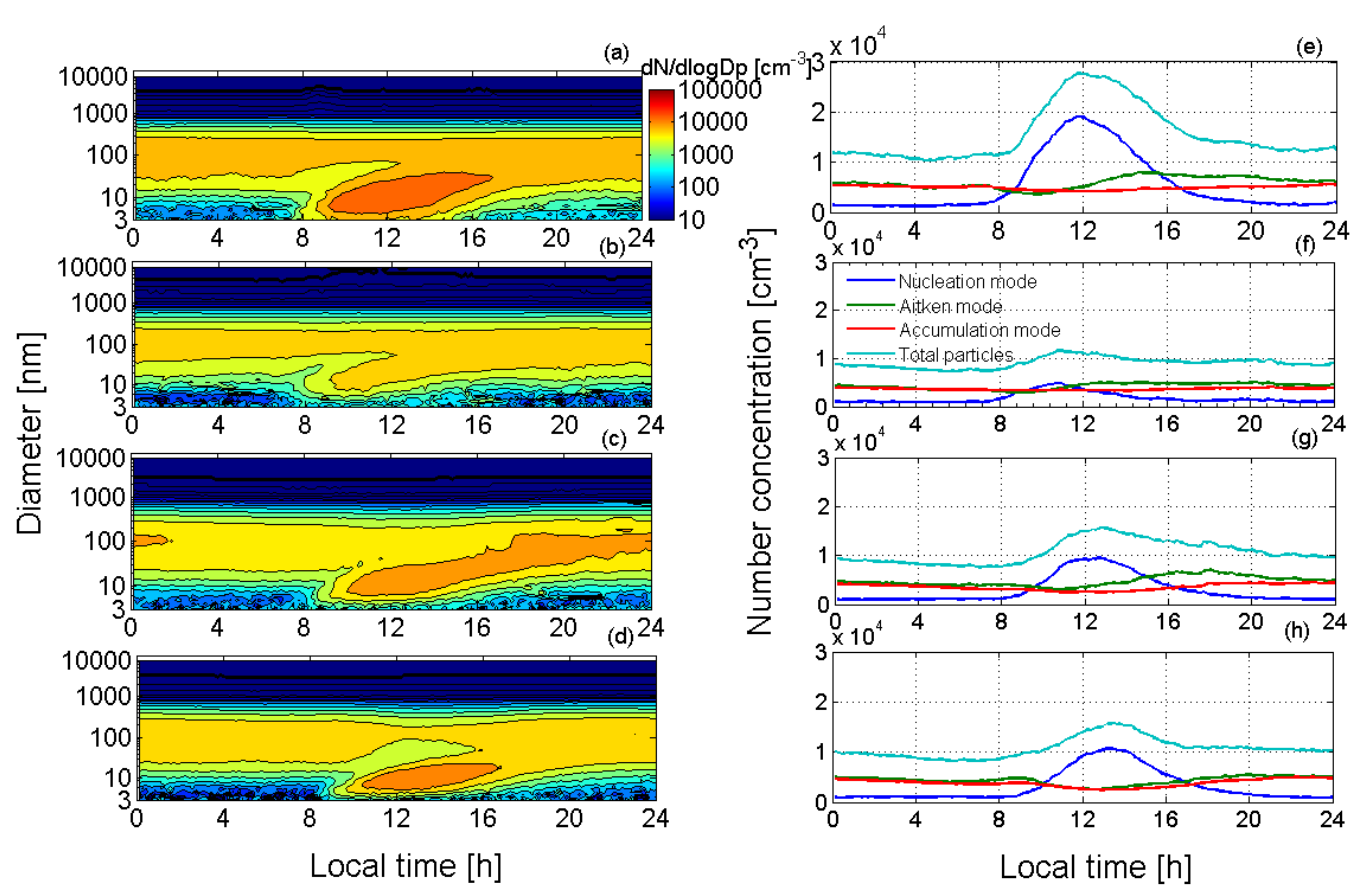

Fig. 3. Mean diurnal variations of the particle number size distributions (left) and number concentrations in different modes (right) in spring (a), (e), summer (b), (f), fall (c), (g) and winter (d), (h).

\subsection{Diurnal variations of particle number size distribution}

The diurnal pattern of aerosol number concentration of each mode was investigated separately for different seasons, i.e. spring (March-May), summer (June-August), fall (September-November), and winter (December-February). The seasonal-average particle number concentration of each mode was calculated using the $10 \mathrm{~min}$ resolution data for each season. Figure 3 shows that the diurnal behaviors of particle size distribution (a-d) and particle number concentrations of different modes $(\mathrm{e}-\mathrm{h})$ vary with seasons. As seen in Fig. 3a, the particle size distribution in spring showed the nucleation mode particles, with the minimum diameter of about $3 \mathrm{~nm}$ appeared around 08:00 when NPF events started. The freshly nucleated particles grew to larger sizes due to condensation and coagulation of the existing particles within several hours, which contributed to the increase of Aitken mode and accumulation mode particles. Nucleation mode particles almost disappeared until 16:00. The evolution of particle size distribution in spring showed clear particle formation and growth due to the frequent NPF events. Low $C S$ and the meteorological factors like low temperature, low relative humidity and high solar radiation favor the NPF events (Boy et al., 2002). In summertime (Fig. 3b), the nucleation mode particles appeared around 08:00 at about $10 \mathrm{~nm}$, with the possible explanation that the newly formed particles had grown to larger size when detected. Then the particles grew to larger sizes gradually until the end of the day. In fall
(Fig. 3c) and winter (Fig. 3d), the nucleation mode particles showed around 09:00, a little bit later than that in spring and summer. This could be possibly explained by the difference of sunrise time in different seasons. The sun rose around 07:20 in winter, 06:30 in fall, 05:40 in spring, and 05:00 in summer. The nucleation mode particles started to show at about $5 \mathrm{~nm}$ in fall and winter, a little bit different from spring, $3 \mathrm{~nm}$ and summer, $10 \mathrm{~nm}$, which was probably due to the meteorological factors which affected the NPF events as mentioned above. And also probably because the particles initially formed at different locations and then they grew to different larger sizes when detected.

The diurnal variation of the total particle number concentration and nucleation mode showed the same trend for all seasons (Fig. 3e-h), which indicated the variation of the number concentration of nucleation mode particle took a dominant role in the variation of total particle number concentration at SDZ. The nucleation mode particle concentration reached peaks at different times due to the duration of NPF events. The highest number concentration of nucleation mode appeared in spring due to the most frequently NPF events and the lowest in summer because of high temperature and high relative humidity, together with the stagnant and polluted air masses which could cause the high $C S$, thus inhibited the NPF events (Wu et al., 2007). At SDZ, the mean ambient temperature and relative humidity was $24^{\circ} \mathrm{C}$ and $78 \%$, respectively, and the mean $C S$ was $0.04 \mathrm{~s}^{-1}$ in summer which was two times as the mean $C S$ during NPF events 
$\left(0.02 \mathrm{~s}^{-1}\right)$. The lowest concentrations of Aitken mode particle occurred between 10:00 and 12:00 because of the clean air mass from aloft mixing downward as the development of boundary layer, then increased due to growth of nucleation mode particles or long-range transportation, and remained stable all night until next morning when the mixing boundary layer changed. The lowest accumulation mode particle concentration was observed in the afternoon, which was mainly caused by the higher mixing layer. The diurnal variations of Aitken mode and accumulation mode particle concentration at SDZ were different from those in the urban area of Beijing where the Aitken and accumulation mode had two or three peaks (around 08:00 and 20:00), mainly due to the traffic emissions (Wu et al., 2008).

For gaining insight into the seasonal variations of particle number size distribution, the seasonal median size distributions were taken and then fitted (Table 2). A least squares fitting algorithm was used to parameterize the particle number size distributions by a multiple lognormal function (Birmili et al., 2001). Three modes $(i=1,2,3)$ were used corresponding to the nucleation mode, Aitken mode, and accumulation mode, respectively. The log-normal distribution is expressed as (Seinfeld and Pandis, 1998):

$\frac{d N}{d \log D_{p}}=\sum_{i=1}^{n} \frac{N_{i}}{\sqrt{2 \pi} \log \sigma_{i}} \exp \left(-\frac{\left(\log D_{p}-\log \bar{D}_{p, i}\right)^{2}}{\left.2\left(\log \sigma_{i}\right)^{2}\right)}\right.$

where $N_{i}$ is the total number concentration of the mode $i$, $\bar{D}_{p, i}$ is the median diameter of mode $i, \sigma_{i}$ is the geometric mean standard deviation of the distribution and $\mathrm{n}$ is the number of the modes. In this study, $\log$ means always $\log 10$.

As shown in Table 2, fitted number concentrations of three modes, $N_{1}, N_{2}$, and $N_{3}$ were all higher in spring than those in the other seasons as a result of frequent NPF events with high formation rates (discussed in the following paragraph). The geometric mean diameter in summer was higher than those in other seasons. In summer, high condensable vapor concentration favored condensational growth of particles. Fall was a harvest time, so agricultural biomass burning might contribute to the accumulation mode particles. Li et al. (2007) showed that geometric mean diameters of particles emitted by all kinds of biofuels combustion were in the range from $110 \mathrm{~nm}$ to $200 \mathrm{~nm}$. In addition, the larger geometric mean diameters of accumulation mode particles in summer and fall should be associated with pollution episodes, which were characterized by high number concentrations in the accumulation mode particles (Wu et al., 2008). The parameterized geometric mean diameters of nucleation mode $(16-20 \mathrm{~nm})$ and the number concentrations of Aitken mode (10 100-12 $400 \mathrm{~cm}^{-3}$ ) were higher in urban Beijing (Wu et al., 2008) than those in this study, which could be explained to a larger extent by the vehicular traffic activities in the urban area. The geometric mean diameter of the accumulation mode in Beijing (117-148 nm) was much lower than that at SDZ (173-199 nm), which indicated the particles condensa- tional growth during the air mass long-range transportation from the urban to the rural site.

\subsection{Back trajectories analysis}

Transport of air constituents from source regions to receptor locations can be qualitatively described by numerical back trajectories. To investigate the impact of meteorological transport on the particle number concentrations at SDZ, $72 \mathrm{~h}$ backward trajectories were calculated using the HYSPLIT 4 model (Hybrid Single-Particle Lagrangian Integrated Trajectory) (Draxler and Rolph, 2003). A simple grouping of various trajectory pathways can provide a more realistic representation of plume dispersion to categorize the source region (Verma et al., 2007). For SDZ, 3-D back trajectories were calculated four times for each day, 00:00, 06:00, 12:00 and 18:00 UTC, terminating in a height of $100 \mathrm{~m}$ a.g.l. 2192 trajectories were calculated and used to do the air mass cluster analysis. In this work, we applied a k-means cluster algorithm similar to that described in Engler et al. (2007). As a distance measure between individual trajectories, longitude and latitude (in degrees) as well as the height of the trajectory above the ground were considered for each hourly trajectory point. To reduce the overemphasis of trajectory points far away, the distance measure was weighted by a function that decreased linearly from the receptor point to the end of the $72 \mathrm{~h}$-trajectory. To compare horizontal (degree) and vertical (meter) distances, several cluster algorithm runs were conducted using different weights for the vertical distance. Here, we present results for the weighing factor (the weighing factor for latitude, longitude and vertical distance is 1,1 and 0.00001 , respectively) that separated the clusters in terms of mean particle number size distributions best.

Figure 4 shows the mean back trajectories for three clusters. The three clusters represented $99 \%$ of the total back trajectories, i.e., cluster 1, 2, 3 accounted for $38 \%, 24 \%$ and $37 \%$, respectively. As can be seen in Fig. 4, clusters mainly originated from two directions, northwesterly (cluster 1,2 ) and southeasterly (cluster 3 ). The mean back trajectories showed significant differences in direction but also in length, and therefore represented the main classes of atmospheric flow conditions over north-eastern China. Cluster 1 from Mongolia passed over Inner Mongolia and Hebei province, cluster 2 from Russia passed over Mongolia, Inner Mongolia and Hebei province, while cluster 3 from Bohai passed over the North China Plain region. Cluster 1 and 2 were from high altitudes (above $1000 \mathrm{~m}$ ) while cluster 3 was from lower altitudes (below $500 \mathrm{~m}$ ). Air masses originating from northwest were usually connected with the advection of dry and clean continental air into SDZ. Air mass from southeast moved slowly and spent much more time over the industrialized regions favoring accumulation of aerosol particles and condensational growth by vapors. The air mass had a noticeable seasonal variation: the three kinds of clusters appeared at nearly the same frequency (about 32\%) in spring, 
Table 2. Parameterization of Particle Number Size distribution for four seasons. The $\bar{D}_{p, i}, \sigma_{i}$ and $N_{i}$ represent the geometric mean diameter, geometric standard deviation and mean number concentration. Here $i=1,2,3$ corresponds to nucleation mode, Aitken mode and accumulation mode, respectively.

\begin{tabular}{lrrrrrrrrr}
\hline & $N_{1}$ & $\sigma_{1}$ & $\bar{D}_{p, 1}$ & $N_{2}$ & $\sigma_{2}$ & $\bar{D}_{p, 2}$ & $N_{3}$ & $\sigma_{3}$ & $\bar{D}_{p, 3}$ \\
\hline Spring & 19100 & 2.33 & 12 & 9530 & 2.19 & 52 & 6630 & 1.66 & 181 \\
Summer & 3120 & 1.61 & 14 & 7420 & 2.05 & 61 & 4060 & 1.68 & 199 \\
Fall & 12570 & 1.75 & 12 & 7660 & 2.13 & 58 & 3960 & 1.63 & 188 \\
Winter & 12710 & 1.65 & 12 & 6550 & 2.07 & 52 & 5610 & 1.68 & 173 \\
\hline
\end{tabular}
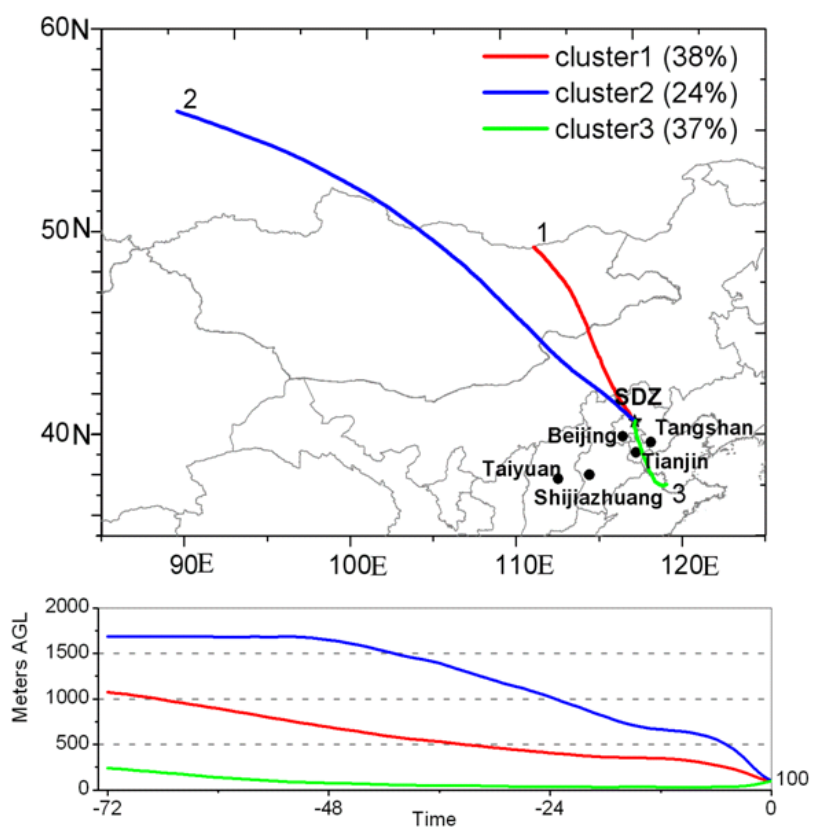

Fig. 4. Mean back trajectories for 3 trajectory clusters arriving at SDZ from different height, dots indicating the main cities of North China Plain.

dominated (with the frequency $70 \%$ ) in summer and cluster 2 dominated in fall (with the frequency $71 \%$ ) and winter (with the frequency $87 \%$ ).

Figure 5 shows the mean diurnal variation of particle number size distributions, averaged over all days (4 back trajectories a day) belonging to the same cluster as mentioned above, i.e., 45 days for cluster 1, 40 days for cluster 2 and 95 days for cluster 3. Significant differences were recognizable: cluster 3 showed the highest number concentrations around a particle size of 100-200 nm. The geometric mean diameter in cluster 3 was relatively stable during the whole day which was consistent with a previous study in Beijing city. Wehner et al. (2008) applied trajectories clustering to analyze 3-year trajectories and their relation to particle number size distributions in Beijing city. They found that the air parcels, whose pathway was similar to cluster 3 of this study, had the highest concentration of $\mathrm{PM}_{1}$ resulting from the uptake of anthro- pogenic pollution in the south of Beijing. In contrast, clusters with fast moving air masses from the northwest (clusters 1, 2) showed a clear nucleation process in the late morning. An explanation for this was efficient vertical dilution of this kind of air mass and therefore a relatively low pre-existing particle surface area (Wehner et al., 2008).

The diurnal variation of the total particle number and mass concentration $\left(\mathrm{PM}_{10}\right)$ on NPF event day and no-event day for different clusters were shown in Fig. 6. It can be seen that all clusters showed a peak of number concentrations on NPF event day, while the number concentrations were relatively stable, with the value about $10000 \mathrm{~cm}^{-3}$ on no-event days (Fig. 6a). The mass concentrations of cluster 3 was much higher than those of others (Fig. 6b), indicating the significant contribution of regional pollution (south of the measurement site) to the mass concentration. NPF event days accounted for $60 \%, 50 \%$ and $8 \%$ of the days when air mass was classified to cluster 1 , cluster 2 and cluster 3, respectively. The analysis above revealed that air masses from northwest favored the NPF events while air masses from southeast were associated with pollution episodes which inhibited NPF events. All above showed air mass had an important effect on NPF events.

\subsection{New particle formation events}

The analysis of NPF events in this study consists of the identification of NPF bursts, obtaining characteristics like growth and formation rates of new particles and the $C S$. The identification of NPF events was based on the principles and methods presented in Dal Maso et al. (2005). A distinct new mode of particles $(3-25 \mathrm{~nm})$ had to appear in the size distribution in the nucleation mode and prevail for at least an hour. In addition, the new mode was required to increase in diameter during its detection. The formation and growth rates and other characteristics of the NPF events were also calculated following the treatment in Dal Maso et al. (2005). The size distributions were parameterized by a least-square log-normal fitting method yielding parameters of 2-3 lognormal modes. So, the time series of geometric mean diameter $\left(D_{p, g}\right)$ of nucleation mode could be obtained, thus, the growth rate $\left(\mathrm{GR}=d D_{p, g} / d t\right.$, given in $\left.\mathrm{nm} / \mathrm{h}\right)$ was calculated. The observed change in new particle concentration 


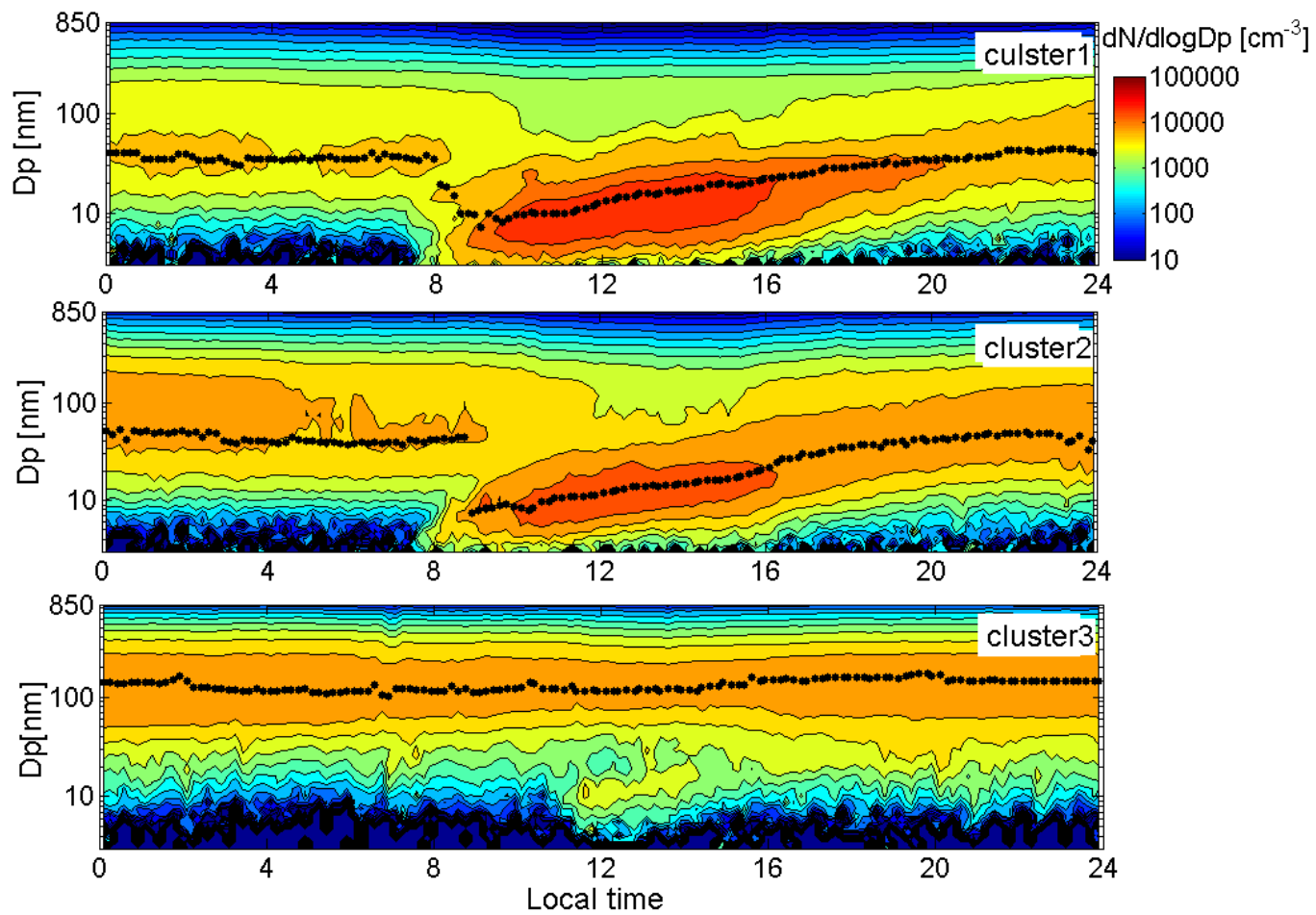

Fig. 5. Mean diurnal evolution of the particle number size distributions, averaged over the three trajectory clusters. Black dots indicate the geometric mean diameter of the dominating mode.
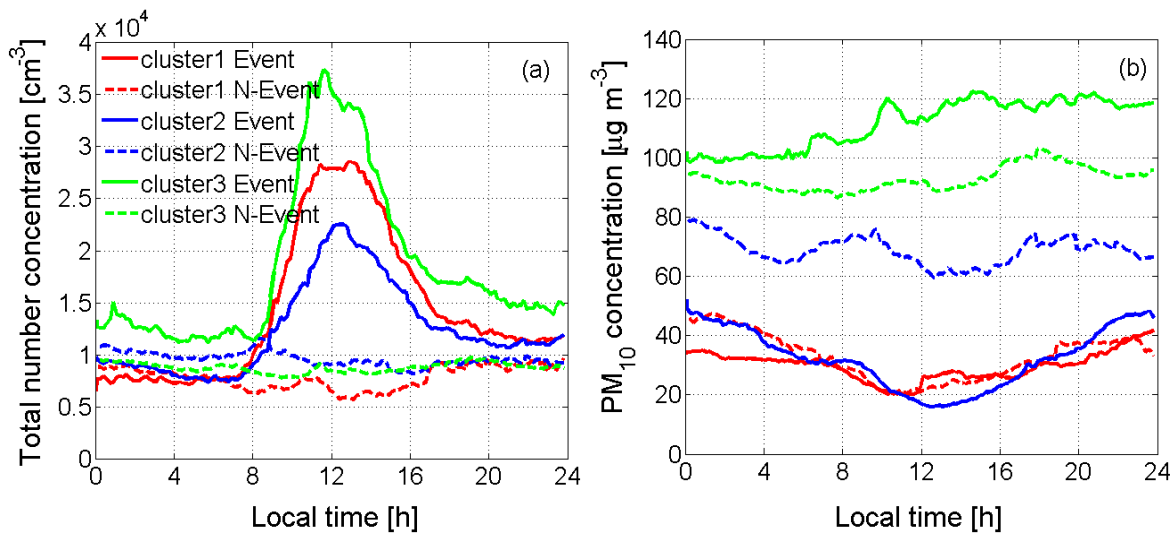

Fig. 6. Diurnal variation of total number concentration (a) and $\mathrm{PM}_{10}$ mass concentration (b) of NPF Event and no-event (N-Event) averaged over all days belonging to the same cluster.

$\left(d N_{\text {nuc }} / d t\right)$ was defined as the temporal change of 3-25 nm particle concentration $\left(N_{\text {nuc }}\right)$ between the start of particle appearance and the peak in $N_{\text {nuc }}$, according to Dal Maso et al. (2007). The observed formation rate of new particles $\left(J_{\text {obs }}\right)$ was calculated according to Eq. (2):

$J_{\mathrm{obs}}=\frac{d N_{\mathrm{nuc}}}{d_{t}}+F_{\mathrm{coag}}$ where $N_{\text {nuc }}$ is the nucleated particle concentration, $F_{\text {coag }}$ is the loss of particles due to coagulation. $F_{\text {coag }}$ can be calculated using Eq. (3):

$F_{\text {coag }}=\operatorname{Coag} S_{\text {nuc }} N_{\text {nuc }}$

where Coag $S_{\text {nuc }}$ is the coagulation sink of particles in the nucleation mode. The reference size for Coag $S_{\text {nuc }}$ is assumed to be the geometric mean diameter of the fitted nucleation 
mode. A mean value of $F_{\text {coag }}$ over the observed formation period was taken.

Coag $S_{\text {nuc }}$ is defined as

$\operatorname{Coag} S\left(D_{p}\right)=\int K\left(D_{p}^{\prime}, D_{p}\right) n\left(D_{p}^{\prime}\right) d D_{p}^{\prime}$

while $K\left(D_{p}^{\prime}, D_{p}\right)$ is the coagulation coefficient (kernel) of particles with sizes $D_{p}$ and $D_{p}^{\prime}$, calculated by using the formula of Fuchs (1964).

$C S$ describes the ability of the size distribution to remove condensable vapors from the atmosphere. In practice, the vapor is assumed to have a very low vapor pressure at the surface of the particle, and molecular properties similar to sulfuric acid (Dal Maso et al., 2005). The parameter $C S$ is defined as

$C S=2 \pi D \sum \beta_{m}\left(D_{p, i}\right) D_{p, i} N_{i}$

where $D_{p, i}$ is the diameter of a particle in size class $i$ and $N_{i}$ is the particle concentration in the respective size class. $D$ is the diffusion coefficient of the condensing vapor. We used the transition regime correction factor $\beta_{m}$ from Fuchs and Sutugin (1970).

During the measurement period, 181 NPF events were observed, corresponding to $36 \%$ of the effective measurement days. Figure 7 shows the annual variation of NPF event occurrence, indicating that NPF events occurred more frequently in spring and winter and less frequently in summer. This variation was quite similar with the frequency of NPF events in Beijing between March 2004 and February 2005 (Wu et al., 2007).

The range of formation rate $\left(J_{\text {obs }}\right)$ varied from 0.7 to $72.7 \mathrm{~cm}^{-3} \mathrm{~s}^{-1}$, with the mean value $8 \mathrm{~cm}^{-3} \mathrm{~s}^{-1}$, which was lower than the results observed at some urban sites, such as in Beijing, 3.3-81.4 $\mathrm{cm}^{-3} \mathrm{~s}^{-1}$ (Wu et al., 2007), St. Louis, with the mean value, $17 \mathrm{~cm}^{-3} \mathrm{~s}^{-1}$ (Qian et al., 2007), but much higher than that at some rural sites, such as Hyytiälä, Finland, $0.7 \mathrm{~cm}^{-3} \mathrm{~s}^{-1}$, Melpitz, Germany, $4.6 \mathrm{~cm}^{-3} \mathrm{~s}^{-1}$ and San Pietro Capofiume, Italy, $3.6 \mathrm{~cm}^{-3} \mathrm{~s}^{-1}$ (Jaatinen et al., 2009). However, the formation rate at SDZ was comparable with the results observed in boundary layer regional nucleation events $0.01-10 \mathrm{~cm}^{-3} \mathrm{~s}^{-1}$ at most other sites (Kulmala et al., 2004). The contribution of the coagulation loss flux $F_{\text {coag }}$ was on average $40 \%$ of the total observed rate, which was quite close to the average ratio of coagulation loss to formation rate observed in Beijing, 0.41 (Yue et al., 2010), meaning coagulation loss was the same important as the net rate of increase of nucleation mode particles $\left(d N_{\text {nuc }} / d t\right)$. The growth rate (GR) ranged from 0.3 to $14.5 \mathrm{~nm} \mathrm{~h}^{-1}$, with the mean value $4.3 \mathrm{~nm} \mathrm{~h}^{-1}$, close to the growth rate in Beijing 0.3$11.2 \mathrm{~nm} \mathrm{~h}^{-1}$ (Wu et al., 2007) and also in the range of typical particle growth rates $1-20 \mathrm{~nm} \mathrm{~h}^{-1}$ in mid-latitudes (Kulmala et al., 2004), but higher than that at Hyytiälä, $2.9 \mathrm{~nm} \mathrm{~h}^{-1}$ (Jaatinen et al., 2009), and lower than that at some sites, such as Melpitz, $6.2 \mathrm{~nm} \mathrm{~h}^{-1}$, San Pietro Capofiume, $6.1 \mathrm{~nm} \mathrm{~h}^{-1}$

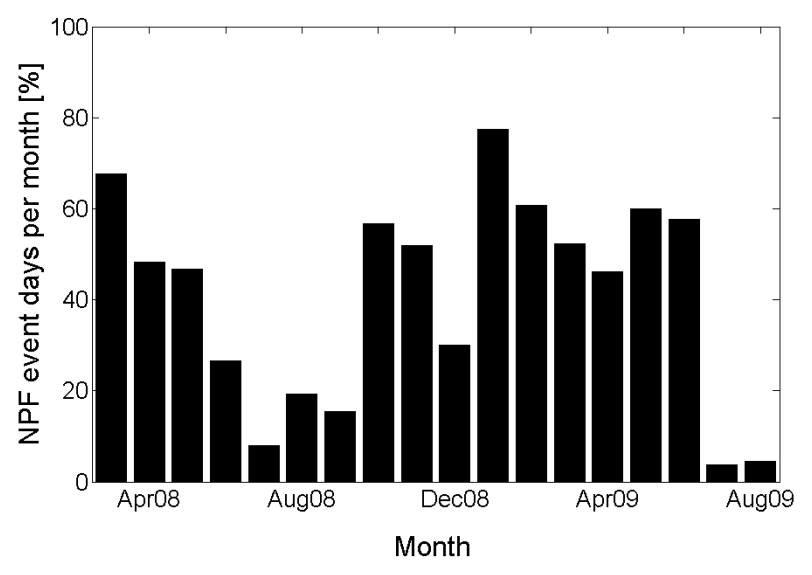

Fig. 7. Frequency of NPF event days in each month.

(Jaatinen et al., 2009) and St. Louis, $5.9 \mathrm{~nm} \mathrm{~h}^{-1}$ (Qian et al., 2007).

The annual variations of formation and growth rates were shown in Fig. 8, indicating that the formation rate was higher in spring while the growth rate was higher in summer. An explanation for this observation was the low $C S$ and meteorological condition, e.g. solar radiance, low temperature and humidity favoring the new particle formation in spring. In summertime the enhancement of photochemical and biological activities together with the stagnant air masses preventing exchange with cleaner air contributed to the particle growth caused by condensation of low volatile vapors which resulted in higher $C S$ than other seasons and prevented NPF to be observed. During NPF events $C S$ was usually low, with mean value of $0.02 \mathrm{~s}^{-1}$.

\subsection{The effects of new particle formation events: case study}

In the following, we focused on 13 March 2008, which was a typical new particle formation event. New particles were formed by nucleation in the morning followed by a clear growth to accumulation mode indicated by the "bananashaped" temporal development of the number size distribution (Fig. 9a). For this event, the $J_{\text {obs }}$ was $14.9 \mathrm{~cm}^{-3} \mathrm{~s}^{-1}$ and GR was $3.8 \mathrm{~nm} \mathrm{~h}^{-1}$. In Fig. 9b, the number concentrations of nucleation mode $\left(N_{\text {nuc }}\right)$, Aitken mode $\left(N_{\text {ait }}\right)$, and $80-850 \mathrm{~nm}\left(N_{80-850 \mathrm{~nm}}\right)$ particles were calculated, respectively. Nucleation started at about 08:00 and $N_{\text {nuc }}$ increased sharply to about $70000 \mathrm{~cm}^{-3}$. Then the newly

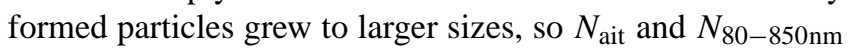
increased with a few hours time lag. The wind direction was mainly from northeast and west which corresponded to the clean air mass. Nucleated particles, when grew up to $50-100 \mathrm{~nm}$, can principally act as cloud condensation nuclei (CCN) (Kerminen et al., 2005). Thus, the number concentration of particles in the range of $80-850 \mathrm{~nm}$ was cal- 

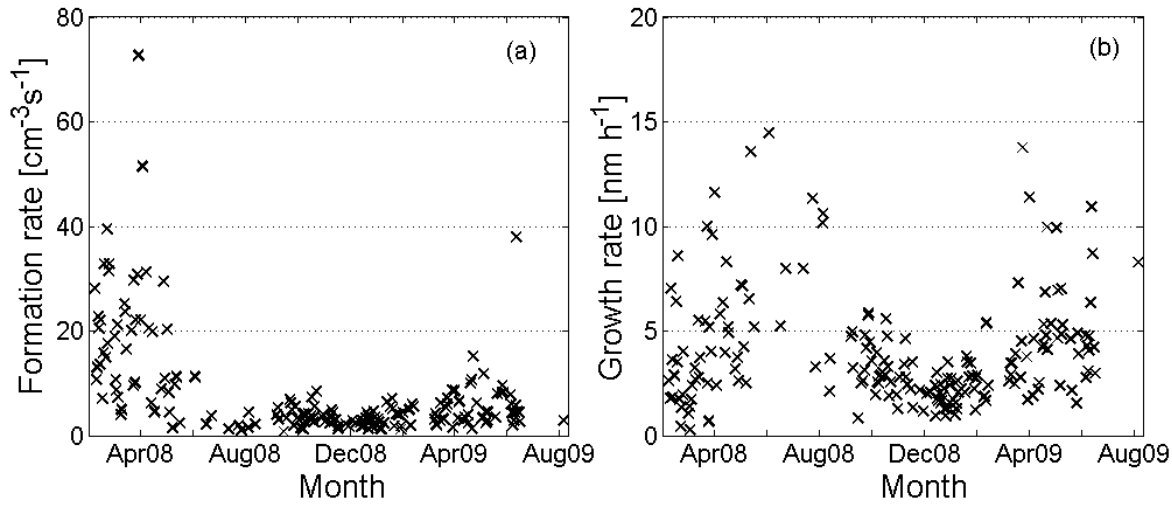

Fig. 8. The variation of formation rate (a) and growth rate (b) during measurement.

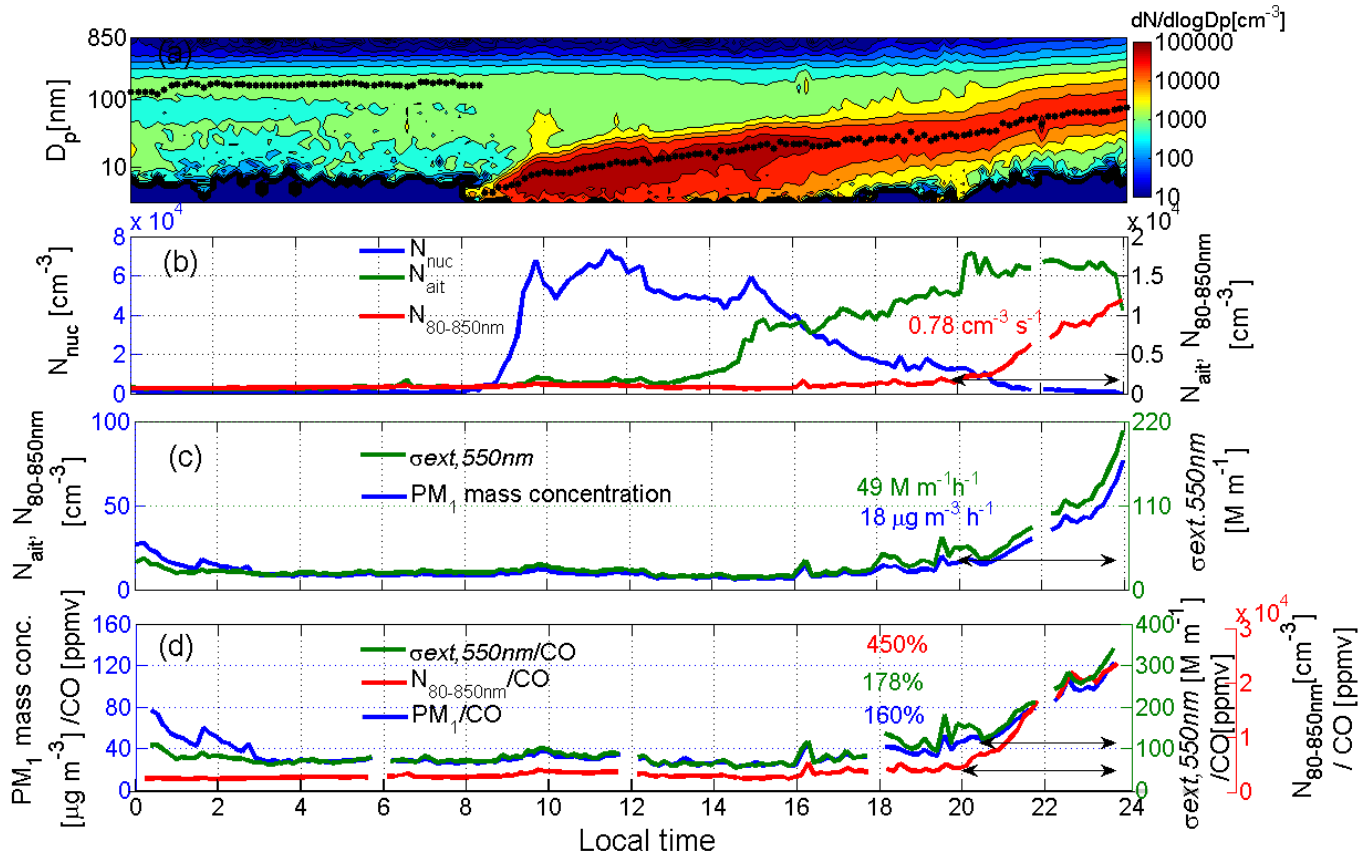

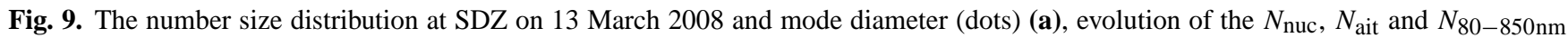
respectively (b), evolution of $\sigma_{\text {ext, } 550 \mathrm{~nm}}$, extinction coefficient at $550 \mathrm{~nm}$ and $\mathrm{PM}_{1}$ mass concentration calculated from TDMPS data (c) and the normalized $N_{80-850 \mathrm{~nm}}, \mathrm{PM}_{1}$ mass concentration and $\sigma_{\text {ext,550nm }}$ by the concentration of CO.

culated as the number concentration of potential CCN. The newly formed particles grew into the $\mathrm{CCN}$ size range after 20:00. The mean $N_{80-850 \mathrm{~nm}}$ increase rate was about $0.78 \mathrm{~cm}^{-3} \mathrm{~s}^{-1}$ during the time period from 20:00 to 24:00, indicating that new particle formation events contributed significantly to the number concentration of $\mathrm{CCN}$. The result of CAREBeijing-2006 also revealed that the nucleation mode grew very quickly into the size range of $\mathrm{CCN}$, and the $\mathrm{CCN}$ size distribution was dominated by the growing nucleation mode (Wiedensohler et al., 2009).
Furthermore, new particles can grow to larger sizes, which also affect the optical properties of the atmospheric particles (Allan et al., 2006). In this study, the dry aerosol extinction coefficients were reconstructed based on the measured distributions and different mixing states (external and internal) of elemental carbon (EC) and non-light-absorbing species (Cheng et al., 2006) utilizing a Mie code (Bohren et al., 1998), to derive the bounding values for the real mixing state. The mass concentration of EC was assumed to be constant at $2.12 \mu \mathrm{g} \mathrm{m}^{-3}$ which was the mean daily-average concentration during nearly two years measurement at SDZ (Yan et al., 2008). The density of $B C$ was taken as $1.5 \mathrm{~g} \mathrm{~cm}^{-3}$. 

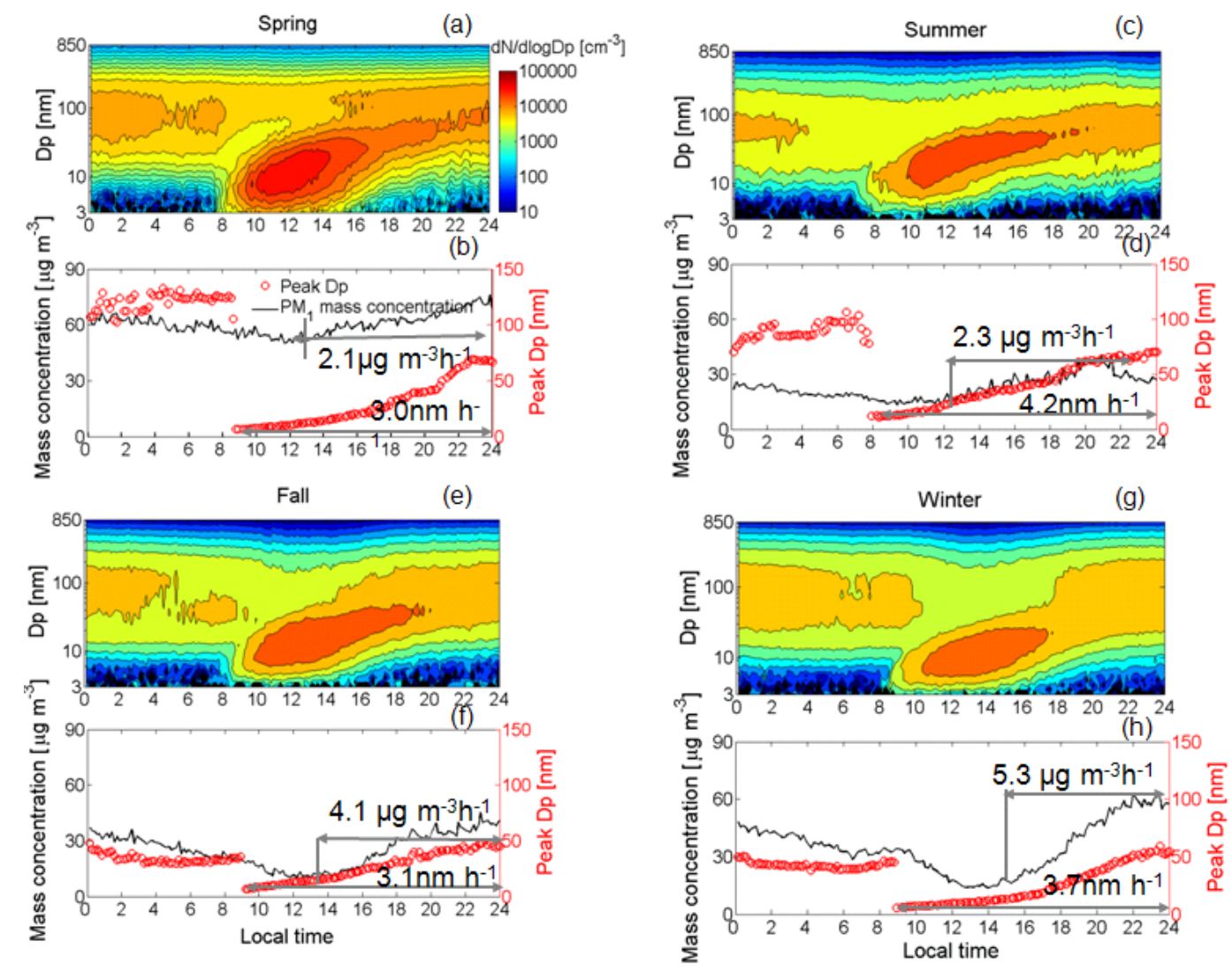

Fig. 10. The evolutions of the particle size distributions (a), (c), (e), (g), $\mathrm{PM}_{1}$ mass concentration derived from number size distributions and mean diameter of the dominating mode from mode fitting to the average particle size distributions (b), (d), (f), (h) from only new particle formations events in four season.

The refractive index used for non-light-absorbing component was $1.55-10^{-7} i$ (Sloane, 1984) and the refractive index of EC was 1.80-0.54i (d'Almeida et al., 1991). The difference of extinction coefficient in external or internal mixing states was less than $10 \%$, and the average of these values was supposed as the real extinction coefficient $\sigma_{\text {ext }, 550 \mathrm{~nm}}$. As shown in Fig. $9 \mathrm{c}, \sigma_{\text {ext, } 550 \mathrm{~nm}}$ increased at the rate of $49 \mathrm{Mm}^{-1} \mathrm{~h}^{-1}$ from 20:30 to the end of day.

The $\mathrm{PM}_{1}$ mass concentration was calculated using measured number size distribution with assumed density of $1.7 \mathrm{~g} \mathrm{~cm}^{-3}$. The $\mathrm{PM}_{1}$ mass showed a significant increase from 20:30 to 24:00 with the average growth rate $18 \mu \mathrm{g} \mathrm{m}^{-3} \mathrm{~h}^{-1}$ (see Fig. 9c), which was consistent with the previous results at Yufa site, a rural site south of Beijing (Wiedensohler et al., 2009).

In order to exclude possible physical effects such as evolution of boundary layer and advection, the concentration of $\mathrm{CO}$ was used for normalizing the particle number concentration, mass concentration and extinction coefficient (Su et al., 2008). As seen in Fig. 9d, the normalized number concentration of particles in the range of $80-850 \mathrm{~nm}$ increased by $450 \%$ from 20:00 to 24:00, and the normalized $\mathrm{PM}_{1}$ mass concentration and $\sigma_{\text {ext, } 550 \mathrm{~nm}}$ increased by $160 \%$ and $178 \%$ from 20:30 to 24:00, respectively. The analysis above indicated that condensational growth of nucleated particles resulted in an increase in the number concentration of potential $\mathrm{CCN}$, aerosol mass concentration and extinction coefficient, through which affected the climate and air quality.

There were about 20\% (36 events) of the NPF events classified as the "typical" events as described above, which were indicated by nucleation burst and followed by the particles growing into the accumulation mode continuously and clearly. The $\mathrm{PM}_{1}$ mass growth rate ranged from 0.6$19.2 \mu \mathrm{g} \mathrm{m}^{-3} \mathrm{~h}^{-1}$ during mass concentration increasing period, with the mean value, $4.9 \mu \mathrm{g} \mathrm{m}^{-3} \mathrm{~h}^{-1}$. And the increase rate of number concentration of potential $\mathrm{CCN}$ was 0.03 $0.85 \mathrm{~cm}^{-3} \mathrm{~s}^{-1}$ during the number concentration increasing period, with the mean value, $0.24 \mathrm{~cm}^{-3} \mathrm{~s}^{-1}$. All above showed the distinct effect of NPF events on the aerosol mass loading and the potential $\mathrm{CCN}$ concentration.

All NPF events were selected to obtain mean diurnal particle size distributions and mass concentrations for the different seasons, as shown in Fig. 10. The particle mean diameter of the dominating mode (Peak diameter) was derived by 
mode fitting of the mean diurnal particle size distributions. The mean growth rates of the nucleation mode for spring, summer, fall and winter were $3.0,4.2,3.1$ and $3.7 \mathrm{~nm} \mathrm{~h}^{-1}$, respectively. The highest particle diameter growth rate appeared in summer because of the high condensable vapor concentration. The plots above showed a nearly linear increase in $\mathrm{PM}_{1}$ mass concentrations and the particle mean diameter emphasized the mass contribution and the particle growth as a result of NPF events. During the time period from noon to the end of the day, the mean $\mathrm{PM}_{1}$ mass growth rates for the four seasons were 2.1, 2.3, 4.1 and $5.3 \mu \mathrm{g} \mathrm{m}^{-3} \mathrm{~h}^{-1}$, respectively. The growth rates in fall and winter were much higher. There is however no clear explanation for this mass growth rate.

\section{Conclusions}

One and a half years continuous measurements were conducted at a rural site, Shangdianzi (SDZ), from March 2008 to August 2009, with the equipment of TDMPS and APS. The measurements covered the size range from $3 \mathrm{~nm}$ to $10 \mu \mathrm{m}$. This was the first long-term investigation of particle number size distributions at a regional background site in the North China Plain. It provided new insights into the evolution of particle number size distribution and new particle formation events for testing and validating regional and global climate models.

During the measurement, the number concentration of nucleation mode, Aitken mode, accumulation mode, coarse mode and total particles was $3.6 \pm 7.9 \times 10^{3} \mathrm{~cm}^{-3}$, $4.4 \pm 3.4 \times 10^{3} \mathrm{~cm}^{-3}, \quad 3.5 \pm 2.8 \times 10^{3} \mathrm{~cm}^{-3}, \quad 2 \pm 3 \mathrm{~cm}^{-3}$ and $1.2 \pm 0.9 \times 10^{4} \mathrm{~cm}^{-3}$, respectively. The number concentration at SDZ had a significant seasonal variation. The peak of the total particle number concentration appeared in spring due to the frequent new particle formation events and the minimum in summer. The diurnal variation of particle number concentration was also influenced by new particle formation events. The nucleation mode particle bursts caused also peaks in total particle number concentrations and later also Aitken mode particles reached their maximum as a result of newly formed particle condensational growth.

Back trajectory analysis revealed that air masses arriving at SDZ mainly originated from northwest and southeast. Polluted air masses from urban areas of Beijing, and even some polluted areas in south of Beijing at North China Plain, could be easily transported to SDZ along with the southeasterly origin, while relatively clean air masses were transported to SDZ mainly from northwest. In summer, the southeasterly air mass dominated, while in other seasons the northwesterly air mass dominated. On average, air masses from northwestern clean areas favored the new particle formation events. Air masses from southeast were usually related to high PM mass concentration because they were slow-moving and vertically stable could favor the accumulation of anthropogenic emis- sions mainly from North China Plain. In this situation, the condensation sink of pre-existing particles were high, which could inhibit the new particle formation events. The cluster analysis in SDZ was quite similar to that in Beijing (Wehner et al., 2008).

New particle formation events occurred quite frequently at SDZ, amounting to $36 \%$ of all the effective measurement days. The range of formation rate varied from 0.7 to $72.7 \mathrm{~cm}^{-3} \mathrm{~s}^{-1}$, and the coagulation loss part contributed to about $40 \%$. The growth rate ranged from 0.3 to $14.5 \mathrm{~nm} \mathrm{~h}^{-1}$. For typical NPF events, the condensational growth of newly formed particles not only contributed to particle sizes which had the potential to act as $\mathrm{CCN}$, with the increase rate 0.03 $0.85 \mathrm{~cm}^{-3} \mathrm{~s}^{-1}$ and the mean value, $0.24 \mathrm{~cm}^{-3} \mathrm{~s}^{-1}$, but also increased the aerosol mass concentration, with the $\mathrm{PM}_{1}$ mass growth rate ranging from 0.6 to $19.2 \mu \mathrm{g} \mathrm{m}^{-3} \mathrm{~h}^{-1}$ and the mean value, $4.9 \mu \mathrm{g} \mathrm{m}^{-3} \mathrm{~h}^{-1}$. The NPF events also had distinct effect on extinction coefficient, but this effect was not evaluated in quantity in this study.

Acknowledgements. This work was supported by European Integrated project on Aerosol Cloud Climate and Air Quality Interactions, EUCAARI (036833), The China International Science and Technology Cooperation Project (2009DFA22800), the National Natural Science Foundation of China (40575063), National Basic Research Program of China (2011CB403401), and key project of CAMS (2010Z002). The authors would also like to thank the Shangdianzi staff for operating and maintaining the instruments at the station. And we highly appreciated that $\mathrm{Xu}$ Xiaobin and Lin Weili providing the reactive gas data.

Edited by: V.-M. Kerminen

\section{References}

Allan, J. D., Alfarra, M. R., Bower, K. N., Coe, H., Jayne, J. T., Worsnop, D. R., Aalto, P. P., Kulmala, M., Hytylinen, T., Cavalli, F., and Laaksonen, A.: Size and composition measurements of background aerosol and new particle growth in a Finnish forest during QUEST 2 using an Aerodyne Aerosol Mass Spectrometer, Atmos. Chem. Phys., 6, 315-327, doi:10.5194/acp-6-315-2006, 2006.

Barsanti, K. C., McMurry, P. H., and Smith, J. N.: The potential contribution of organic salts to new particle growth, Atmos. Chem. Phys., 9, 2949-2957, doi:10.5194/acp-9-2949-2009, 2009.

Birmili, W., Stratmann, F., and Wiedensohler, A.: Design of a DMA-based size spectrometer for a large particle size range and stable operation, J. Aerosol Sci., 30(4), 549-554, 1999.

Birmili, W., Wiedensohler, A., Heintzenberg, J., and Lehmann, K.: Atmospheric particle number size distribution in central Europe: 
Statistical relations to air mass and meteorology, J. Geophys. Res., 32, 5-18, 2001.

Bohren, C. F. and Huffman, D. R.: Absorption and scattering of light by small particles, John Wiley and Sons, Wiley-Intersci., New York, USA, 544 pp., 1998.

Boy, M. and Kulmala, M.: Nucleation events in the continental boundary layer: Influence of physical and meteorological parameters, Atmos. Chem. Phys., 2, 1-16, doi:10.5194/acp-2-1-2002, 2002.

Boy, M., Kulmala, M., Ruuskanen, T. M., Pihlatie, M., Reissell, A., Aalto, P. P., Keronen, P., Dal Maso, M., Hellen, H., Hakola, H., Jansson, R., Hanke, M., and Arnold, F.: Sulphuric acid closure and contribution to nucleation mode particle growth, Atmos. Chem. Phys., 5, 863-878, doi:10.5194/acp-5-863-2005, 2005.

Cheng, Y. F., Eichler, H., Wiedensohler, A., Heintzenberg, J., Zhang, Y. H., Hu, M., Herrmann, H., Zeng, L. M., Liu, S., Gnauk, T., Brüggemann, E., and He, L. Y.: Mixing state of elemental carbon and non-light-absorbing aerosol components derived from in situ particle optical properties at Xinken in Pearl River Delta of China, J. Geophys. Res., 111, D20204, doi:10.1029/2005JD006929, 2006.

Dal Maso, M., Kulmala, M., Riipinen, I., Wagner, R., Hussein, T., Aalto, P. P., and Lehtinen, K. E. J.: Formation and growth of fresh atmospheric aerosols: eight years of aerosol size distribution data from SMEAR II, Hyytiälä, Finland, Boreal Env. Res., 10, 323336, 2005.

Dal Maso, M., Sogacheva, L., Aalto, P. P., Riipinen, I., Komppula, M., Tunved, P., Korhonen, L., Suur-Uski, V., Hirsikko, A., Kurten, T., Kerminen, V.-M., Lihavainen, H., Viisanen, Y., Hansson, H.-C., and Kulmala, M.: Aerosol size distribution measurements at four Nordic field stations: identification, analysis and trajectory analysis of new particle formation bursts, Tellus, 59, 350-361, 2007.

d' Almeida, G., Keopke, P., and Shettle, E.: Atmospheric aerosolglobal climatology and radiative characteristics, A. Deepak, Hampton, Va, 1991.

Dominici, F., Peng, R. D., Bell, M. L., Pham, L., McDermott, A., Zeger, S. L., and Samet, J. M.: Fine particulate air pollution and hospital admission for cardiovascular and respiratory diseases, J. American Medical Association., 295, 1127-1134, 2006.

Draxler, R. R. and Rolph, G. D.: HYSPLIT (HYbrid SingleParticle Lagrangian Integrated Trajectory). Model access via NOAA ARL READY Website: http://www.arl.noaa.gov/ready/ hysplit4.html, NOAA Air Resources Laboratory, Silver Spring, MD, 2003.

Engler, C., Rose, D., Wehner, B., Wiedensohler, A., Brggemann, E., Gnauk, T., Spindler, G., Tuch, T., and Birmili, W.: Size distributions of non-volatile particle residuals $\left(D_{p} ; 800 \mathrm{~nm}\right)$ at a rural site in Germany and relation to air mass origin, Atmos. Chem. Phys., 7, 5785-5802, doi:10.5194/acp-7-5785-2007, 2007.

Fuchs, N. A.: The mechanics of aerosols, Pergamon, New York, USA, 1964.

Fuchs, N. A. and Sutugin, A. G.: Highly dispersed aerosols, Pergamon, New York, USA, 1971.

Gao, J., Wang, J., Cheng, S. H., Xue, L. K., Yan, H. Z., Hou, L. J., Jiang, Y. Q., and Wang, W. X.: Number concentration and size distributions of submicron particles in Jinan urban area: Characteristics in summer and winter, J. Environ. Sci., 19, 1466-1473, 2007.
Gao, J., Wang, T., Zhou, X. H., Wu, W. S., and Wang, W. X.: Measurement of aerosol number size distributions in the Yangtze River delta in China: Formation and growth of particles under polluted conditions, Atmos. Environ., 43, 829-836, 2009.

Harrison, R. M., Jones, M., and Collins, G.: Measurements of the physical properties of particles in the urban atmosphere, Atmos. Environ., 33, 309-321, 1999.

Hamed, A., Joutsensaari, J., Mikkonen, S., Sogacheva, L., Dal Maso, M., Kulmala, M., Cavalli, F., Fuzzi, S., Facchini, M. C., Decesari, S., Mircea, M., Lehtinen, K. E. J., and Laaksonen, A.: Nucleation and growth of new particles in Po Valley, Italy, Atmos. Chem. Phys., 7, 355-376, doi:10.5194/acp-7-355-2007, 2007.

Hong, Y. C., Lee, J. T., Kim, H., Ha, E. H., Schwartz, J., and Christiani, D. C.: Effects of Air Pollutants on Acute Stroke Mortality, Environ. Health Persp., 110, 181-197, 2002.

Hussein, T., Puustinen, A., Aalto, P. P., Mäkelä, J. M., Hämeri, K., and Kulmala, M.: Urban aerosol number size distributions, Atmos. Chem. Phys., 4, 391-411, doi:10.5194/acp-4-391-2004, 2004.

Iida, K., Stolzenburg, M. R., and McMurry, P. H.: Effect of working fluid on sub- $2 \mathrm{~nm}$ particle detection with a laminar flow ultrafine condensation particle counter, Aerosol Sci. Technol., 43, 81-96, doi:10.1080/02786820802488194, 2009.

Jaatinen, A., Hamed, A., Joutsensaari, J., Mikkonen, S., Birmili, W., Wehner, B., Spindler, G., Wiedensohler, A., Decesari, S., Mircea. M., Facchini. M.C., Junninen, H., Kulmala, M., Lehtinen, K. E. J., and Laaksonen, A.: A comparison of new particle formation events in the boundary layer at three different sites in Europe, Boreal Env. Res., 14, 481-498, 2009.

Kerminen, V.-M. and Kulmala, M.: Analytical formulae connecting the "real" and the "apparent" nucleation rate and the nuclei number concentration for atmospheric nucleation events, J. Aerosol Sci., 33, 609-622, 2002.

Kerminen, V.-M., Lihavainen, H., Komppula, M., Viisanen, Y. and Kulmala, M.: Direct observational evidence linking atmospheric aerosol formation and cloud droplet activation, Geophys. Res. Lett., 32, L14803, doi:10.1029/2005GL023130, 2005.

Kivekäs, N., Sun, J., Zhan, M., Kerminen, V.-M., Hyvärinen, A., Komppula, M., Viisanen, Y., Hong, N., Zhang, Y., Kulmala, M., Zhang, X.-C., Deli-Geer, and Lihavainen, H.: Long term particle size distribution measurements at Mount Waliguan, a highaltitude site in inland China, Atmos. Chem. Phys., 9, 5461-5474, doi:10.5194/acp-9-5461-2009, 2009.

Kulmala, M.: How Particles Nucleate and Grow, Science, 302, 1000-1001, 2003.

Kulmala, M., Vehkamäkia, H., Petäjä, T., Dal Maso, M., Lauri, A., Kerminen, V. -M., Birmili, W., and McMurry, P.H.: Formation and growth rates of ultrafine atmospheric particles: a review of observations, J. Aerosol Sci., 35, 143-176, 2004.

Kulmala, M., Riipinen, I., Sipilä, M., Manninen, H. E., Petäjä, T., Junninen, H., Dal Maso, M., Mordas, G., Mirme, A., Vana, M., Hirsikko, A., Laakso, L., Harrison, R.M., Hanson, I., Leung, C., Lehtinen, K. E. J., and Kerminen, V. -M.: Toward direct measurement of atmospheric nucleation, Science, 318, 89-92, 2007.

Laakso, L., Koponen, I. K., Mönkkönen, P., Kulmala, M., Kerminen, V.-M., Wehner, B., Wiedensohler, A., Wu, Z. J., and Hu, M.: Aerosol particles in the developing world: a comparison between New Delhi in India and Beijing in China, Water Air Soil 
Poll., 173, 5-20, 2006.

Li, X. H., Duan, L., Wang, S. X., Duan, J. C., Guo, X. M., Yi, H. H., Hu, J. N., Li, C., and Hao, J. M.: Emission characteristics of particulate matter from rural household biofuel combustion in China, Energy Fuels, 21, 845-851, 2007.

Lin, W., Xu, X., Zhang, X., and Tang, J.: Contributions of pollutants from North China Plain to surface ozone at the Shangdianzi GAW Station, Atmos. Chem. Phys., 8, 5889-5898, doi:10.5194/acp-8-5889-2008, 2008.

Liu, S., Hu, M.,Wu, Z. J., Wehner. B., Wiedensohler. A., and Cheng, Y. F.: Aerosol number size distribution and new particle formation at a rural/coastal site in Pearl River Delta (PRD) of China, Atmos. Environ., 25, 6275-6283, 2008.

Middleton, W. E. K.: Vision Through the Atmosphere, U. Toronto Press, Toronto, 205 pp., 1952.

Qian, S., Sakurai, H., and McMurry, P. H.: Characteristics of regional nucleation events in urban East St. Louis, Atmos. Environ., 41, 4119-4127, 2007.

Pope, III. C. A. and Dockery, D. W.: Health Effects of Fine Particulate Air Pollution: Lines that Connect, J. Air Waste Manage. Assoc., 56, 709-742, 2006.

Riipinen, I., Sihto, S.-L., Kulmala, M., Arnold, F., Dal Maso, M., Birmili, W., Saarnio, K., Teinilä, K., Kerminen, V.-M., Laaksonen, A., and Lehtinen, K. E. J.: Connections between atmospheric sulfuric acid and new particle formation during QUEST III-IV campaigns in Heidelberg and Hyytiälä, Atmos. Chem. Phys., 7, 1899-1914, doi:10.5194/acp-7-1899-2007, 2007.

Rosenfeld, D., Lohmann, U., Raga, G. B., O’Dowd, C. D., Kulmala, M., Fuzzi, S., Reissell, A., and Andreae, M. O.: Flood or Drought: How Do Aerosols Affect Precipitation?, Science, 321, 1309-1313, 2008.

Seinfeld, J. H. and Pandis, S. N.: Atmospheric chemistry and physics of air pollution, John Wiley and Sons, Inc., New York, USA, 1998.

Sloane, C. S.: Optical properties of aerosols of mixed composition, Atmos. Environ., 18, 871-878, 1984.

Solomon, S., Qin, D. H., Manning, M., Marquis, M., Averyt, K., Tignor, M., Miller, H. L., and Chen, Z. L.: Intergovernmental Panel on Climate Change (IPCC): Summary for policymakers, Climate Change 2007: The Physical Science Basis, Cambridge University Press, Cambridge, 2007.

Stanier, C. O., Khlystov, A. Y., and Pandis, S. N.: Ambient aerosol size distributions and number concentrations measured during the Pittsburgh Air Quality Study (PAQS), Atmos. Environ., 38, 3275-3284, 2004.

Su, H., Cheng, Y. F., Cheng, P., Zhang, Y. H., Dong, S. F., Zeng, L. M., Wang, X. S., Slanina, J., Shao, M., and Wiedensohler, A.: Observation of nighttime nitrous acid (HONO) formation at a non-urban site during PRIDE-PRD 2004 in China, Atmos. Environ., 42, 6219-6232, 2008.

Sipilä, M., Lehtipalo, K., Attoui, M., Neitola, K., Petäjä, T., Aalto, P. P., O'Dowd, C. D., and Kulmala, M.: Laboratory verification of PH-CPC's ability to monitor atmospheric sub-3 nm clusters, Aerosol Sci. Technol., 43, 126-135, 2009.

Tang, J., Wang, M. L., Cheng, H. B., Ding, G. A., Yu, X. M., Zhou, H. G., and Liu, G.P.: Variation Characteristics of Ambient NMHCs at Shangdianzi and Lin'an Regional GAW Sites, Acta Meteorol. Sin., 21, 334-341, 2007.
Twomey. S.: Atmospheric aerosols, Elsevier, New York, USA, 1977.

Tuch, T. M., Haudek, A., Müller, T., Nowak, A., Wex, H., and Wiedensohler, A.: Design and performance of an automatic regenerating adsorption aerosol dryer for continuous operation at monitoring sites, Atmos. Meas. Tech., 2, 417-422, doi:10.5194/amt-2-417-2009, 2009.

Verma, S., Venkataraman, C., Boucher, O., and Ramachandran, S.: Source evaluation of aerosols measured during the Indian Ocean Experiment using combined chemical transport and back trajectory modeling, J. Geophys. Res., 112, D11210, doi:10.1029/2006JD007698, 2007.

Wang, W., Ma, J. Z., Hatakeyama, S., Liu, X. Y., Chen, Y., Takami, A., Ren, L. H., and Geng, C. M.: Aircraft measurements of vertical ultrafine particles profiles over Northern China coastal areas during dust storms in 2006, Atmos. Environ., 42, 5715-5720, 2008.

Wehner, B. and Wiedensohler, A.: Long term measurements of submicrometer urban aerosols: statistical analysis for correlations with meteorological conditions and trace gases, Atmos. Chem. Phys., 3, 867-879, doi:10.5194/acp-3-867-2003, 2003.

Wehner, B., Birmili, W., Ditas, F., Wu, Z., Hu, M., Liu, X., Mao, J., Sugimoto, N., and Wiedensohler, A.: Relationships between submicrometer particulate air pollution and air mass history in Beijing, China, 2004-2006, Atmos. Chem. Phys., 8, 6155-6168, doi:10.5194/acp-8-6155-2008, 2008.

Wiedensohler, A., Cheng, Y. F., Nowak, A., Wehner, B., Achtert, P., Berghof, M., Birmili, W., Wu, Z. J., Hu, M., Zhu, T. Takegawa, N., Kita, K., Kondo, Y., Lou, S. R., Hofzumahaus, A., Holland, F., Wahner, A., Gunthe, S. S., Rose, D., Su, H., and Pöschl, U.: Rapid aerosol particle growth and increase of cloud condensation nucleus activity by secondary aerosol formation and condensation: A case study for regional air pollution in northeastern China, J. Geophys. Res., 114, D00G08, doi:10.1029/2008JD010884, 2009.

Willeke, K. and Baron, P. A.: Aerosol measurement: Principles, techniques and applications, Van Nostrand Reinhold, New York, USA, 1993.

Woo, K. S., Chen, D. R., Pui, D. Y. H., and McMurry, P. H.: Measurement of Atlanta aerosol size distributions: observations of ultrafine particle events, Aero. Sci. Technol., 34, 75-87, 2001.

Wu, Z. J., Hu, M., Liu, S., Wehner, B., Bauer, S., Ma $\beta$ ling, A., Wiedensohler, A., Petäjä, T., Dal Maso, M., and Kulmala, M.: New particle formation in Beijing, China: Statistical analysis of a 1-year data set, J. Geophys. Res., 112, D09209, doi:10.1029/2006JD007406, 2007.

Wu, Z. J., Hu, M., Lin, P., Liu, S., Wehner, B., and Wiedensohler, A.: Particle number size distribution in the urban atmosphere of Beijing, China, Atmos. Environ., 42, 7967-7980, 2008.

Yan, P., Tang, J., Huang, J., Mao, J. T., Zhou, X.J., Liu, Q., Wang, Z. F., and Zhou, H. G.: The measurement of aerosol optical properties at a rural site in Northern China, Atmos. Chem. Phys., 8 , 2229-2242, doi:10.5194/acp-8-2229-2008, 2008.

Yue, D. L., Hu, M., Wu, Z. J., Wang, Z. B., Guo, S., Wehner, B., Nowak, A., Achtert, P., Wiedensohler, A., Jung, J. S., Kim,Y. J., and Liu, S. H.: Characteristics of aerosol size distributions and new particle formation in the summer in Beijing, J. Geophys. Res., 114, D00G12, doi:10.1029/2008JD010894, 2009. 
Yue, D. L., Hu, M., Zhang, R. Y., Wang, Z. B., Zheng, J., Wu, Z. J., Wiedensohler, A., He, L. Y., Huang, X. F., and Zhu, T.: The roles of sulfuric acid in new particle formation and growth in the mega-city of Beijing, Atmos. Chem. Phys., 10, 4953-4960, doi:10.5194/acp-10-4953-2010, 2010.
Zhang, R., Suh, I., Zhao, J., Zhang, D., Fortner, E. C., Tie, X., Molina, L. T., and Molina, M. J.: Atmospheric new particle formation enhanced by organic acids, Science, 304, 1487-1490, 2004. 